\title{
Social justice required: Youth at the margins, churches and social cohesion in South Africa
}

\begin{tabular}{|c|c|}
\hline \multicolumn{2}{|c|}{$\begin{array}{l}\text { Authors: } \\
\text { Elisabet le Roux }{ }^{1} \text { (D) } \\
\text { Elina Hankela }{ }^{2} \text { (D) } \\
\text { Zahraa McDonald }^{3} \text { (D) }\end{array}$} \\
\hline \multicolumn{2}{|c|}{$\begin{array}{l}\text { Affiliations: } \\
{ }^{1} \text { Unit for Religion and } \\
\text { Development Research, } \\
\text { Stellenbosch University, } \\
\text { South Africa }\end{array}$} \\
\hline \multicolumn{2}{|c|}{$\begin{array}{l}{ }^{2} \text { Department of Religion } \\
\text { Studies, University of } \\
\text { Johannesburg, South Africa }\end{array}$} \\
\hline \multicolumn{2}{|c|}{$\begin{array}{l}{ }^{3} \text { Centre for International } \\
\text { Teacher Education, Cape } \\
\text { Peninsula University of } \\
\text { Technology, South Africa }\end{array}$} \\
\hline \multicolumn{2}{|c|}{$\begin{array}{l}\text { Corresponding author: } \\
\text { Elisabet le Roux, } \\
\text { eleroux@sun.ac.za }\end{array}$} \\
\hline \multicolumn{2}{|c|}{$\begin{array}{l}\text { Dates: } \\
\text { Received: } 24 \text { Apr. } 2018 \\
\text { Accepted: } 27 \text { July } 2018 \\
\text { Published: } 11 \text { Oct. } 2018\end{array}$} \\
\hline \multicolumn{2}{|c|}{$\begin{array}{l}\text { How to cite this article: } \\
\text { Le Roux, E., Hankela, E. \& } \\
\text { McDonald, Z., 2018, 'Social } \\
\text { justice required: Youth at the } \\
\text { margins, churches and social } \\
\text { cohesion in South Africa', } \\
\text { HTS Teologiese Studies/ } \\
\text { Theological Studies 74(3), } \\
\text { a5046. https://doi.org/ } \\
\text { 10.4102/hts.v74i3.5046 }\end{array}$} \\
\hline \multicolumn{2}{|c|}{$\begin{array}{l}\text { Copyright: } \\
\text { (C) 2018. The Authors } \\
\text { Licensee: AOSIS. This } \\
\text { is licensed under the } \\
\text { Creative Commons } \\
\text { Attribution License. }\end{array}$} \\
\hline \multicolumn{2}{|l|}{ Read online: } \\
\hline 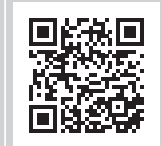 & $\begin{array}{l}\text { Scan this QR } \\
\text { code with your } \\
\text { smart phone or } \\
\text { mobile device } \\
\text { to read online. }\end{array}$ \\
\hline
\end{tabular}

The divides within South African society remain stark, also for youth born after apartheid officially ended in 1994. At the same time, adherence to a faith tradition is statistically high among South Africans, and faith-based organisations (FBOs), an umbrella term including but not limited to churches, also have high levels of youth participation. Scholars have identified positive connotations between FBOs, civil society, social welfare and social care. Within this broader context, and based on qualitative interviews and focus group data, this article explores how young people in two South African communities experience isolation and separation in their everyday life and how they perceive the role of churches, in particular, in strengthening or weakening this sense of marginalisation. On a theoretical level, the article reflects on how two dimensions of social cohesion relate to one another in young people's everyday life. The first dimension comprises of aspects such as participation, diversity and trust, whereas the second relates to justice and equity. Special attention is given to the relationship between the two dimensions of social cohesion in the context of local churches. We argue that the experiences and perceptions of the interviewed young people support the view promoted by some scholars that, for social cohesion to actualise in society, issues related to social justice must be addressed. Furthermore, churches could play a more central role in doing so - at least more so than what appears to currently be the case.

\section{Introduction}

The divides within South African society remain stark, also for youth born after apartheid officially ended in 1994. Most communities that were forcibly removed and relocated during the apartheid era continue to experience the effects of unequal development (Butler 2017). Those living in such neighbourhoods within South Africa's cities and towns continue to be less integrated into mainstream social institutions than those from areas reserved for the white population during apartheid. In particular, participation in formal educational and economic institutions is decidedly less prevalent, especially with regard to young people (Alexander 2010:31).

The 2001 census showed that adherence to a faith tradition was very common among South Africans (Vorster 2013:149). In South Africa, organised religion holds a prominent place, and scholars have identified positive connotations between FBOs (used in this article as an umbrella term including, but not limited to, churches), civil society, social welfare and social care (Maharaj et. al. 2008; Piper 2009; Swart et al. 2012). In addition, scholars have found that FBOs have the highest levels of youth participation, compared to other civil society organisations (Everatt, Shezi \& Jennings 2005:113; Shezi, Everatt \& Jennings 2003:119, 127-128). However, we do not know enough about how, if at all, FBOs - or churches as a particular type of FBO - impact young people's experiences of isolation or inclusion. More specifically, little research has been done on how FBOs in general, or churches in particular, impact the experiences of social cohesion among marginalised youth.

This article explores the experiences of isolation and separation of marginalised young people in two predominantly coloured communities ${ }^{1}$ : Riverlea in Johannesburg in the Gauteng Province and Franschhoek in the Western Cape Province. The primary data used in this article consists of qualitative interviews and focus groups conducted with young people from these two communities, the majority of whom were not in education, employment or training (NEET) at the time. Based on our analysis, the young people articulated a deep sense of separation and isolation, and mainly did not discuss experiences of churches attempting to promote or realise social justice in their context.

\footnotetext{
1.The term "coloured communities' is used here to connote communities that emerged as a consequence of specific apartheid policies in particular, the Population Registration Act of 1950 and Groups Areas Act of 1950 (see Ebr-Vally 2001:44-52). These communities descend from African, Asian and European people (see Adhikari 2005). Within the South African context, this is an accepted and nonpejorative way to refer to communities of this descent.
} 
As a conceptual framework, the article draws on an understanding of social cohesion that is linked closely with the notion of social justice. This is done in order to explore the young people's everyday experiences and perceptions of churches and their role in influencing the youth's experiences of isolation and separation. In particular, our interest is in how two dimensions of social cohesion, one emphasising aspects such as diversity, reconciliation, participation and social relations and the other relating to justice and equity, manifest and link with one another in the context of the case studies and, in particular, the churches in these communities. We argue that the experiences of these young people support the view promoted by some scholars that, for social cohesion to actualise in society, issues related to social justice must be addressed, be it by churches or other actors.

The article first explains the approach to social cohesion adopted for the analysis and outlines the methodology used. The findings from the two case studies are then discussed and analysed in three sections: spatial separation, social separation and youth perceptions of churches' responses.

\section{Dimensions of social cohesion}

The article employs a conceptual framework provided by a topical notion in both academic and policy discourses, also in South Africa, namely social cohesion. Although some have argued that the term has been used vaguely (cf. Bernard 1999; De Beer 2014), it is beyond the scope of this article to enter into a comprehensive analysis of the definitions and discourse surrounding the term. Instead, we draw on chosen scholars' contribution to this discourse, and in particular on De Beer's (2014) conceptualisation of the notion. This allows us to construct a lens that lets us address questions arising in the two case study contexts about youth experiences of churches, isolation and separation.

For the purposes of this article, we understand the notion of social cohesion to comprise of two dimensions. The first dimension emphasises aspects such as participation, diversity, reconciliation and social relations; the second highlights justice and equity (De Beer 2014; also see Berger-Schmitt 2000). In South Africa, these two dimensions are also reflected in the public domain, see, for instance, the deliberations of the Department of Arts and Culture (e.g. DAC 2012). Also, for example, Terreblanche's remarks on South African politics can be read to highlight the connectedness of the two dimensions (Angell \& De Beer 2018). He argues that the deep structural injustices of South Africa's colonial and apartheid past have not been addressed, and he uses the Truth and Reconciliation Commission (TRC) as an example of an initiative that leaned on reconciliation (part of the first dimension of social cohesion) while neglecting justice (the second dimension) (Terreblanche 2014:141-142).

In line with Terreblanche's emphasis on justice, De Beer (2014:2) maintains that 'any vision of social cohesion probably stands or falls by how well it ensures the inclusion of the most "invisible" or most marginal or most vulnerable people of society'. In other words, De Beer's vision of social cohesion converges with how Nancy Fraser (2000:5) conceives of a parity of participation, which implies that justice requires social arrangements that permit all ... members of society to interact with one another as peers'. Following Fraser (1999, 2000), we understand the notion of social justice to require parity in participation - entailing both a just redistribution of resources and an equal recognition of different identities.

Our case studies could be thought of as settings of marginalisation or 'the most "invisible"' (De Beer 2014:2), and so we pay close attention to the social justice dimension of social cohesion. Taking seriously this dimension - and its connectedness with the other dimension - allows analysis to take into account the impact of structural injustice on individual behaviour. Failing to recognise the importance of social justice for social cohesion can lead to a fundamental misunderstanding of what drives people's behaviour and circumstances, as argued by De Beer (2014):

Exclusion, in practices of social control, is often seen not as systemic forces deliberately excluding people but rather as people's anti-social behaviour, thus blaming the victim or the excluded for their own exclusion. (p. 4)

Fitzpatrick and Jones's (2005) research suggests that those who prioritise solely the first dimension (inclusion and participation) may be using social control and coercion to ensure cohesion. This kind of cohesion neglects social justice, and De Beer (2014) argues that cohesion of this nature cannot last:

Where social cohesion or rather a version of cohesion that is smoothing over fault lines or fractures, co-opting socially excluded and violated people into visions of social cohesion that are not fundamentally addressing the injustices against them is prioritised over social justice, it is probably truer to think of it as social control and not as social cohesion. The cohesiveness of such an approach cannot be sustained in the long-run except through excessive policing. (p. 6)

In South Africa, structural injustice is perhaps nowhere more concretely embodied than in the spatial design and ownership of communities. This is also the case in the communities we engaged with in Riverlea and Franschhoek. Both were created by apartheid legislation that enforced separation of racial groups. Thus, De Beer's (2014) emphasis on the importance of land restitution or redistribution and spatial transformation - as aspects of what equity and justice mean - for social cohesion is particularly relevant to this study.

This article's reflection on how churches impact social cohesion is not in itself novel, for religion and religious institutions have long been viewed as contributing to social cohesion. Through a common belief and value system, people are bonded. Durkheim (1995[1912]), for example, here emphasising the first dimension of social cohesion, saw the goal of religious rites and rituals as:

arous(ing) certain ideas and feelings, to join the present to the past and the individual to the collectivity. In fact, not only are these ceremonies incapable of serving other ends, but the faithful themselves seek nothing more from them. (p. 382) 
However, by taking seriously the social justice dimension of social cohesion, we engage more critically with churches' ability and methods of building social cohesion. By analysing the perceptions and experiences of marginalised young people in these two communities, we interrogate basic assumptions about religion and churches' role in influencing social cohesion.

\section{Methodology}

As part of a South-North research project entitled 'Youth at the Margins: A Comparative Study of the Contribution of Faith-Based Organisations to Social Cohesion in South Africa and Nordic Europe' (hereafter referred to as the YOMA project), six case studies were conducted: four in South Africa and one each in Norway and Finland (cf. Swart 2013). The case studies focused on marginalised young people, particularly those NEET, and their experiences of social cohesion as influenced by FBOs. This article uses data from two of the case studies, while also drawing on the work done for two chapters written on these case studies (Hankela \& Nel 2018; Orsmond et al. 2018). ${ }^{2}$ The YOMA project investigated the influence of FBOs, which, according to the definition adopted in the project, also included faith communities such as churches. An FBO is regarded here as 'any organisation that derives inspiration and guidance from the teachings and principles of the faith or from a particular interpretation or school of thought within the faith' (Clarke \& Jennings 2008:6). However, in this article, we shift to focusing only on churches, the shift being reflective of our data. In Riverlea and Franschhoek, the young people spoke mostly about Christian churches, and thus, their experiences of FBOs were for the most part experiences of churches. By the term 'church', we understand 'a regularised social organisation of believers' (Giddens 1978:86), meaning that both practicing faith and some kind of organisational structure characterise a church. Essentially then, the terms 'FBO' and 'church' could in this article be used interchangeably, as churches are included under the umbrella of FBOs. However, in an attempt to represent the young people's accounts more precisely, the term 'church' is used in discussing the findings of this article.

Franschhoek is one of the oldest towns in South Africa. South African apartheid legislation divided Franschhoek, demarcating separate living areas for different racial groups, some of which are relatively far removed from the town proper. In this predominantly Christian town (cf. Stats SA 2016), these divides continue, with especially the rise in property prices hampering reintegration. In short, the unjust distribution of resources continues. Although still producing grapes and fruit, the town has evolved to become a major tourist destination, so much so that foreign property investment has increased to the extent that some regard it as a 'second wave of colonialism' (Van Laar et al. 2014:194). In Franschhoek, the interviewees came from two

2.We acknowledge the contribution of our team members: Reginald Nel, Edward Orsmond and Anita Cloete. In addition, we acknowled funding received for the Orsmond and Anita Cloete. In addition, we acknowledge funding received for the work related to the YOMA project from the National Research Foundation, the Academy of Finland, Stellenbosch University and the College of Human Sciences (UNISA). The views and arguments in this article are, however, those of the authors. neighbourhoods, namely Groendal and Langrug; but in this article, we simply refer to Franschhoek. Groendal and Langrug are both areas that were developed separately for coloured people in Franschhoek. The town hosts a large number of churches. There are no mosques in Franschhoek.

Riverlea, in turn, is a predominantly coloured neighbourhood on the western side of Johannesburg. Established in 1965, it was created as a destination for coloured people who were forcibly removed from other areas of Johannesburg (Community Agency for Social Enquiry 2004). However, Riverlea also has a growing black African population (cf. Census 2011), coming not only from South Africa but also from other African countries. Riverlea hosts three mosques and a large number of churches.

The fieldwork in both Franschhoek and Riverlea was coordinated based on the guidelines and interview guides for the YOMA project, and was conducted during 2015 and 2016. In Franshhoek, 22 young people were interviewed individually. Seventeen of these young people were affiliated with Christianity, one was from the Rastafarian religion and four had no religious affiliation. Fifteen of the 22 young people were female and 7 male, while 19 were mixed race and 3 black African. The individual interviews were followed by two focus groups with young people (one group with women and one with men). In Riverlea, 18 interviews with young people were conducted. All these young people were or had been in some way affiliated with Christianity. Twelve were female and 6 male, while 15 were mixed race and 3 black African. The individual interviews were followed by two mixed-gender focus group discussions. All the names of the interviewees have been anonymised in the article.

In both cases, the data were recorded, transcribed and analysed using Atlas.ti. In Franschhoek, some interviews were conducted in Afrikaans, and in these cases, they were first translated into English. It should be noted that, though in both sites additional interviews were conducted with people working with or close to youth, these interviews are not used in this article. This was done to keep the focus on the experiences and opinions of the young people.

\section{Spatial isolation and separation from the formal labour market}

Apartheid is commonly understood as a policy of spatial separation and unequal development. Nevertheless, the TRC process mentioned earlier did not address structural inequalities or reparation at the macro level (Sayed et al. 2016). Nor did any comprehensive intervention occur in post-apartheid South Africa to address structural inequality resulting from the gross unequal development rendered by apartheid policies (Sayed et al. 2016). The young people in Franschhoek, as well as in Riverlea, expressed what such structurally unequal development continued to mean in their everyday lives. Those in Franschhoek experienced isolation, because of its rurality. As one interviewee explained her situation: 
'Before last Thursday, I was at the clinic with my child's lung problem, the clinic is supposed to have sent me to hospital. Thursday the clinic sent a bus for me, I sat here from the morning half past seven to half past three in the afternoon. It's a neverending thing ... from half past seven to half past three. ... they have to give him oxygen three times and from then I went home. Thursday evening my child's eyes turned inside out (due to struggling to breathe) ... two, three times ... I phoned the ambulance ... the third time they phoned they said that they're now going to send one to us.' (Elanza, 22, female)

Elanza's utter reliance on a public ambulance to take a very sick child to the hospital speaks of isolation of stark proportions and of a daily struggle to obtain basic services in her community. But the isolation was also experienced in the mundane aspects of daily life, in how little changed from day to day. A number of Franschhoek participants spoke about the monotony of their daily lives. Carolynne explained how every day was for her:

'I wake up, I wash, I sit outside the whole time ... Yes, you sit outside all the time, then again you watch TV, and you are outside again... It is not lekker (nice).' (18, female)

While some young people in Riverlea reported access to services, others' description of their daily life resonated with Carolynne's experience. Natasha, for instance, described her days as follows:

'It's boring. ... I just wake up, I clean, I maybe do the washing or ironing, I look after the children, I must bath them, feed them, cook. That's what I do every day and then I will sleep, watch TV with them, and stuff. Every day that's what I do. And it's like a routine, like it's something you get used to doing. It's very boring.' (23, female)

Yet, there was an awareness that this was not how life was for others. Franschhoek is a tourism hub throughout the year, and Jan-Jan (21, male) spoke wistfully of how these tourists were able to travel to different places, coming to Franschhoek and then leaving again: 'We have some tourism around here. Travelling, purchases by people from outside and incoming people who only come and look here at Franschhoek and then they go again'. Linda (27, female) from Riverlea also echoed the idea that there was a different life beyond the neighbourhood. She envisaged her future life to be outside Riverlea. Interestingly, though, such a life would be in a close by, predominantly coloured neighbourhood (such as Eldorado Park or Westbury) and not an affluent Johannesburg suburb such as Sandton.

Being employed was identified as a way of escaping the isolation and monotony. Not only would a job give one something to do, it would provide money for one to do other things as well. Yet, Aneshka (26, female) from Franschhoek was not optimistic about her chances of finding work:

'I try. I handed in my CV during the week. It is not ... I don't think the CV's help, because all over in town my CV has already been handed in.' $(26$, female)

In Riverlea, many interviewees spoke about unemployment. Monique described what not managing to participate in the mainstream job market meant to some young people:
'You know most of us, most of us are doing what we're doing because we don't have a job, or, ja, I think jobs is the most common thing that nobody really has. ... You know, some girls will go and sell themselves for those things (to be able to buy nappies for their babies) because of not having a job. Smoking, drugs: not having a job. Drinking every day: not having a job.' (19, female)

Monique's remark reflects an understanding of unemployment shaping the space in Riverlea. Here widespread unemployment appears constitutive of what is possible in that space. In a similar manner, unemployment can be thought to be shaping what occurs in Franschhoek. In this way, isolation from the mainstream economy works to shape the experiences in certain spaces in particular destructive ways - which are discussed in more detail in the next section.

Young people in Franschhoek and Riverlea described a sense of spatial isolation or, in particular in Franschhoek, a sense of being stuck in the space while seeing others coming and going. In addition, young people expressed notions of separation from the formal labour market with regard not only to (un)employment but also to processes that could be associated with it, for example, fair recruitment processes. Such descriptions and expressions raise questions about social cohesion not only at the neighbourhood level but also between different areas within the city or town. The social arrangements in these two neighbourhoods do not seem to be actively enabling the young people to interact - as peers - with other members of the city or town. These experiences, albeit based on a limited data set, illustrate how the unequal spatial design that South Africa inherited from the apartheid government impacts on both of the two dimensions of social cohesion. A similar conclusion has, moreover, been drawn in another research project that focused on youth in South Africa (Sayed et al 2016).

\section{Contextual factors promoting social separation}

In both Franshhoek and Riverlea, while there were also exceptions, young people spoke about their neighbourhoods and communities in negative terms. For example, Belinda described the part of Riverlea where she stayed as a place where:

'you can't really communicate with people ... because they're always busy with their own stuff, mostly drugs, alcohol. So for you to prevent yourself from that, you have to keep yourself distantly.' (19, female)

Resonating with these broader perceptions of their communities, in both Franschhoek and Riverlea, the young interviewees spoke of friends in conflicting ways. On the one hand, they are a potential source of trouble, but, on the other hand, they can add value to one's life. The latter was, for instance, illustrated by Xavier-John from Franschhoek, when he explained:

'The reason why I chose those friends that I had, is because they were all interested in dancing, just like me. I wanted all the way to be like Michael Jackson. And so we mixed.' (18, male) 
However, while acknowledging the positive stories shared about friends, the negative perceptions attached to friends are of key interest here, as they shed light on the linkages between trust and social justice.

Both the Riverlea and the Franschhoek research teams found that several interviewees connected having friends in general, or having 'bad friends' in particular, to potential trouble. For instance, Bradley from Riverlea, when asked about challenges in his life, spoke of 'mixing with the wrong people ... people that come with, with, you know, different types of bad ideas'. He used to use drugs with his friends and consequently had lost his job:

'It's those kind of friends that, that is the reason why I'm in this situation. I'm not trying to put a blame on them. But I had my own choice and I made the wrong choice and I'm still trying to make up for that.' (24, male)

Many young people described friends as a threat to sobriety and drug avoidance, or 'good behaviour' in general. For example, after attending a rehabilitation centre, Henry (18, male) from Riverlea indicated that he was now only spending time with younger children who were no threat to his sobriety, while Gertjie (24, male) from Franschhoek indicated that he avoided all friends: 'Well, I don't really have friends around here, see ... because my friends that have been with me, they are into drugs'. Belinda $(19$, female) from Riverlea also explained that she was, by choice, mostly by herself, although she also spoke of a few people that she spent time with, such as her boyfriend and an older neighbour.

From the perspective of the first dimension of social cohesion, choosing to stay away from one's peer group raised questions about a lack of trust between young people. Whereas the youth could still build relationships with other social groups, for example, adults or younger children, the lack of faith in constructive horizontal relationships could be viewed as an obstacle to a cohesive community. From this perspective, young people's experiences in Franschhoek and Riverlea depicted a crude expression of an inability of members of society to interact as peers. However, looking beyond the interviewees' negative perception of friends, to the reasons they gave for staying away from other youth, highlights the impact of the environment in which the young people live. Friends were depicted as problematic within the particular contexts of Riverlea and Franschhoek. Separating and isolating oneself from certain friends, or people in general, is then a strategy of avoiding one's life being complicated or one's future prospects hampered. Because of the contextual realities, it appears that some young people were being forced to choose between inclusion with their friends and inclusion into the larger society. Yet, there was no evidence perhaps partly because of our sampling criteria - to suggest that choosing to separate oneself from one's peers led to greater inclusion beyond one's immediate community. Having chosen to avoid bad friends seems not to have led to these young people having jobs or access to people and educational or other opportunities outside of their immediate communities. But regardless of the form of inclusion chosen by youth, such inclusion would be unjust (using Fraser's terms) because of all members of society not interacting with one another as peers. As it stands, it appears that young people are doubly marginalised, with both dimensions of social cohesion absent.

Within these challenging settings, the young people's choices of isolating themselves from peers can be linked to a will to survive and a hope of flourishing. One would hope that community leaders and institutions would be sensitive to why these young people make the choices they do, also when they choose 'bad' friends. Research on drug abuse, for instance, has indicated a strong link between poverty and/or inequality and the problematic use of drugs (Shaw, Egan \& Gillespie 2007), and illustrated the lack of positive impact of interventions that are directed at individual behaviour in a context where the social, cultural and economic environment remains unchanged (Spooner \& Hethringen 2004). However, if one reflects on how some young people spoke about the relationship between churches within these communities and young people who engage in 'bad' behaviour, sensitivity to the social justice component of social cohesion and, in particular, how the youth's anti-social behaviour is linked to poverty and structural injustice do not appear central to this relationship. This is what we discuss next. Here it is important to note that we look at the question from the perspective of our analysis of the young people's views, and the reflection is thus not based on what churches did or how they understood their role in the neighbourhood.

\section{Uni-dimensional responses of churches}

In both Riverlea and Franschhoek, churches form part of the fabric of the community - both physically, through the visibility of their buildings, and by how it is considered natural to be a member of a church or another faith community. All of the Riverlea participants were or had been involved in a church, and only one of the Franschhoek interviewees had never been a member of a church. Young people were socialised, especially within the household, into believing in God and belonging to a faith community, as illustrated by Aneshke from Franschhoek:

'I have always been raised as a Christian. I have an uncle, who is now dead. He was a pastor. My other uncle is a pastor today. My grandmother, my auntie and them all were. They grew up in the church since they were young. Then we went to church with them. They all used to talk about God in our house, so we grew up as Christians.' (26, female)

But while belonging to a church, or another faith community, was quite universal, not all of the participants expressed the same level of commitment. With some of the young people interviewed, more careful questioning revealed that, although they identified themselves as members of a particular church, they rarely attended services or other church activities. Jacques (20, male) from Riverlea, for example, said he only went to church when his grandparents 
told him to do so. Nevertheless, many of these young people still spoke of a particular church that they attended or used to attend or that their family members attended. Moreover, even if some regularly attended different churches, there still remained one church that they seemed to feel they belonged to. While affiliation was thus not an automatic indication of spirituality or even engagement in religious activities, it could be regarded as an indication of a sense of belonging and participation - even in cases where there was very little actual participation. In light of these experiences, churches seem to have facilitated social cohesion, by contributing to the first dimension of social cohesion - through promoting participation and social relations and creating a sense of belonging within the confines of a faith community.

Churches in these two communities provided a space for belonging, by creating alternative, positive spaces of being and participating. As discussed in the previous section, parts of these neighbourhoods could be regarded as difficult places to live, with drug and alcohol abuse being rife. The young people spoke of churches offering alternative identities and spaces that assisted young people in avoiding these dangers. Natasha explained it as follows:

'But with a community like Riverlea ... you get tempted to do worldly things a lot and if you're not persistent in your faith ... you get eaten up by those very quickly.' (23, female)

In this way, churches may play a role in enabling alternative lifestyles and young people appeared to be intentional in affiliating with churches in order to avoid destructive lifestyles. Immediately after deciding to 'end her wild ways', Clarisse from Franschhoek went to church. This was her intervention method and she credits her church for helping her change her ways:

'I liked getting up to things that I shouldn't have done, and one day I just felt but it's not for me. I am going to church one time I had people pray for me and from that day I just felt now I'm finished with the wild business that I was busy with.' (18, female)

Thus, churches were seen as 'positive' spaces of being, creating social cohesion built on 'positive' activities, such as attending services, choir practice, prayer meetings and youth groups, rather than destructive activities such as drug abuse.

But through their attempts to create a cohesive society by promoting a positive sense of community and belonging (thus promoting the first dimension of social cohesion), churches might simultaneously flout the social justice dimension of social cohesion. For instance, in the act of forming a community with an alternative (positive) identity and ethos, churches could be experienced as judgemental, discriminatory or inaccessible. Lerato (21, female) from Riverlea aired strong criticism of churches, portraying churches as exclusionary communities: 'They always criticise, they think they're holier than thou. They, they ... There's not much support going on there'. There were others in Riverlea who explained that they chose not to attend church activities, because of their situation or life choices. Bradley (24, male) said that at first he had stayed away from church because he had needed more time for 'wrongdoings' [drugs] and had then began to feel 'like a stranger to church'. Natasha (23, female) spoke of having stopped participating in a given church group; when asked for a reason, she said she did not know but then explained that she was at the time 'making one mistake after another' and decided not to go back to the church. Yet, it is also to be noted that Natasha discussed a 'mistake' she had made with an older member of her church and got help through this member. While taking distance from church activities was here not linked during the interviews to others' judgement, it nevertheless raises questions of whether young people perceive the church ethos among members to be exclusionary in nature. In Franschhoek, one young woman stated that people were judged at church based on the clothes they wear; another explained that her involvement in church activities was limited as she had had a baby as an unmarried woman. In other words, some young people seemed to feel vulnerable to others' - or perhaps to their own, based on an internalised perception of the ethos of their church - judgement or condemnation in churches. It appears that these young people are not, or do not feel, acknowledged and accepted as equals. These young people's experiences raise questions about whether churches in some instances attempt to foster social cohesion through social control - enforced through (intended or unintended) stigma and discrimination. By upholding rigid ideas about appropriate behaviour, churches, as social organisations, may impede or even prevent full and equal participation between people. Where certain behaviours are not 'acceptable' within the frame of reference of most church members, those who engage in these activities could find it difficult to experience a sense of belonging in the church. Under such circumstances, the capacity of churches towards fostering social cohesion is weakened.

\section{Conclusion}

This article explored the experiences of isolation and separation of marginalised young people in two South African communities, Riverlea and Franschhoek, and looked at how churches impact these experiences. In doing so, the article drew on an understanding of social cohesion linked closely with social justice, as a lens to explore young people's experiences and their perceptions of churches' contribution and response to the isolation and separation of marginalised youth.

Our research suggests that many of the young people we engaged with in these communities experienced a deep sense of separation and isolation that impedes a parity of participation (Fraser 2000). While we do not present this insight as true of all of the young people from Riverlea and Franschhoek (because of the qualitative approach adopted in this article), we believe that the experiences of these selected young people add an important perspective to the discussion about social cohesion in South Africa. Firstly, interviewees described a sense of isolation in their physical spatial location. Historically their neighbourhoods were established to be marginal to mainstream infrastructure and amenities, and 
this legacy continued to inform the experiences of many interviewees. In other words, the absence of just redistribution of resources is clearly constraining equal participation for these young people in Franschhoek and Riverlea. Secondly, the young people experienced separation from the formal labour market. Thirdly, several interviewees spoke of separation between young people: some linked remaining socially connected with one's age-mates in the community to the threat of becoming involved in negative activities that could compromise one's future prospects. Drug and alcohol abuse, associated with unemployment, were among the chief reasons for young people maintaining a distance between themselves and their peers. The experiences of these young people in Franschhoek and Riverlea thus provide an empirical illustration of how the absence of just redistribution generates social arrangements that do not permit all members of society to interact with one another as peers. The absence of just redistribution here flouts a parity of participation and social justice.

In our analysis of the young people's views, we found little to suggest that promoting social justice was a central element in the practice of churches in their neighbourhoods. In the young people's narratives, churches were portrayed as offering a 'safe haven' for young people, allowing them space to separate from 'bad' friends and problematic behaviours. At times, being accepted in these spaces seemed to suggest that one also needed to separate from certain parts of oneself, or at least from certain practices, in order to be recognised and accepted. In the face of wide spread poverty, how certain individuals abusing drugs, or some unmarried mothers, experienced churches, as discussed above, may suggest a lack of sensitivity to or engagement with structural injustice. However, at this point, it is important to remember that our research did not focus on what churches actually did, or how churches' understood their mission, but on how young people experience and perceive churches.

Under the conditions of deprivation engendered by colonialism and apartheid and further spawned by neoliberal capitalism, 'safe havens' ought probably not to be chastised in their entirety. As such, the contribution the young people saw churches making to the first dimension of social cohesion appears to be rather important. As De Beer (2014, emphasis added) notes:

we have to be concerned with the transformation of systems that exclude, even as we seek to accompany, serve and facilitate the inclusion of excluded people in our own communities whilst structural transformation is still underway. (p. 4)

Yet, if the contribution to the first dimension of social cohesion is not accompanied by structural transformation, to which the churches also contribute to as important social organisations in these neighbourhoods, and thus working towards social justice, this uni-dimensionality may be scuppering hope for lasting social cohesion.

Overall, the manner in which isolation and separation feature as an important experience in the young people's everyday life highlights the lack of justice and equity in the context of their lived experiences. We argue that the experiences and perceptions of the young people support the idea that, for social cohesion to actualise in society, issues related to social justice must be addressed. Furthermore, churches (alongside other actors) could play a more significant role in this than what appears to currently be the case. Further research could explore what churches perceive themselves to be doing in this regard and how they could alter their mandate and mission in order to be better able to promote and ensure social justice.

\section{Acknowledgements}

Dr Edward Orsmond, Prof. Anita Cloete and Prof. Reginald Nel were part of the research team conducting the case study fieldwork, as well as co-authors in the two case study book chapters on which this article builds. The authors wish to thank the two anonymous reviewers, who gave valuable feedback on a draft version of this article, and Prof. Ignatius Swart, who served as the editor of the special edition and gave feedback on various versions of the article.

\section{Competing interests}

The authors declare that they have no financial or personal relationship(s) that may have inappropriately influenced them in writing this article.

\section{Authors' contributions}

E.L.R., E.H. and Z.M. contributed equally to the conceptualisation of the article, its design and the writing process. E.L.R. and Z.M. were part of the team conducting the fieldwork in Franschhoek, whereas E.H. was part of the team conducting the fieldwork in Riverlea.

\section{References}

Adhikari, M., 2005, 'Contending approaches to coloured identity and the history of the coloured people of South Africa', History Compass 3(177), 1-16. https://doi. org/10.1111/j.1478-0542.2005.00177.x

Alexander, P., 2010, 'Rebellion of the poor: South Africa's service delivery protests - A preliminary analysis', Review of African Political Economy 37(123), 25-40. https:// doi.org/10.1080/03056241003637870

Angell, O.H. \& De Beer, S., 2018, "'Social cohesion: theoretical exploration of a concept", Unpublished chapter submitted for the YOMA project manuscript in preparation', in Stuck in the margins? Young people and faith-based organisations preparation', in Stuck in the margins?
in South African and Nordic Localities.

Berger-Schmitt, R., 2000, Social cohesion as an aspect of the quality of societies: Concept and measurement, Working paper no. 14, Centre for Survey Research and Methodology, Mannheim. Bernard, P., 1999, 'Social cohesion: A critique', CPRN Discussion Paper no. F/09, Canadian Policy Research Networks, Ottawa.

Butler, A., 2017, Contemporary South Africa, London, Palgrave.

Census 2011, 2012, Census 2011 Statistical release, Statistics South Africa, Pretoria.

Clarke, G. \& Jennings, M. (eds.), 2008, Development, civil society and faith-based organisations: Bridging the sacred and the secular, Palgrave Macmillan, New York.

Community Agency for Social Enquiry, 2004, Voices of the poor: Case studies of urban poverty in the city of Johannesburg, viewed 12 January 2017, from http://www. joburg-archive.co.za/corporate_planning/Case.pdf

De Beer, S., 2014, 'Demythologising social cohesion: Towards a practical theological vision', Verbum et Ecclesia 35(2), 1-12, viewed 24 April 2018, from http://www. scielo.org.za/pdf/vee/v35n2/02.pdf

Department of Arts and Culture (DAC), 2012, Creating a caring and proud society: A national strategy for developing an inclusive and a cohesive South African society, viewed 18 January 2018, from http://www.dac.gov.za/social-cohesion

Durkheim, E., 1995 [1912], The elementary forms of religious life, Free Press, New York. 
Ebr-Vally, R., 2001, 'Diversity in imagined umma', in A. Zegeye (ed.), Socia identities in the New South Africa, vol. 1, pp. 269-300, Maroelana Kwela Books, Cape Town.

Everatt, D., Shezi, S. \& Jennings, R., 2005, 'An attempt to reverse the failure of rural youth development in South Africa', in H. Helve \& G. Holm (eds.), Contemporary youth research: Local expressions and global connections, pp.103-120, Routledge, Louth resedon.
Lond

Fitzpatrick, S. \& Jones, A., 2005, 'Pursuing social justice or social cohesion?: Coercion in street homelessness policies in England', Journal of Social Policy 34(3), 389-406. https://doi.org/10.1017/S0047279405008834

Fraser, N., 1999, 'Social justice in the age of identity politics: Redistribution, recognition and participation', WZB Discussion Paper, FS I 98-108, viewed 24 April 2018, from https://www.ssoar.info/ssoar/bitstream/handle/document/12624/ssoar-1998fraser-social justice in the age.pdf?sequence $=1$

Fraser, N., 2000, 'Social justice in the age of identity politics: Redistribution, recognition and participation', in L. Ray \& A. Sayer (eds.), Culture and economy after the cultural turn, pp. 25-52, Sage, Thousand Oaks, CA.

Giddens, A., 1978, Durkheim, William Collins Sons and Co. Ltd., Glasgow.

Hankela, E. \& Nel, R., 2018, “Keep yourself busy”: Young people, FBOs and social cohesion in Riverlea', Unpublished chapter submitted for the YOMA project manuscript in preparation, Stuck in the Margins? Young people and faith-based organisations in South African and Nordic Localities.

Maharaj, B., Habib, A., Chetty, I., Favis, M., Khan, S., Sithole, P. et al., 2008, 'Religion and development', in A. Habib \& B. Maharaj (eds.), Giving and solidarity: Resource flows for poverty alleviation and development in South Africa, pp. 79-120, HSRC Press, Cape Town

Orsmond, E., Cloete, A., Le Roux, E. \& McDonald, Z., 2018, 'NEET young people in Franschhoek: A story of continued separatedness', Unpublished chapter submitted for the YOMA project manuscript in preparation, Stuck in the Margins Young People and Faith-based Organisations in South African and Nordic Localities.
Piper, L., 2009, 'Faith-based organisations, local governance and citizenship in South Africa', in D. Brown (ed.), Religion and spirituality in South Africa: New perspectives, pp. 54-77, University of KwaZulu-Natal Press, Durban.

Sayed, Y., Badroodien, A., McDonald, Z., Balie, L., De Kock, T., Garisch, C. et al., 2016, Teachers and youth as agents of social cohesion in South Africa, CITE, Cape Town.

Shaw, A., Egan, J. \& Gillespie, M., 2007, Drugs and poverty: A literature review, viewed 24 April 2018, from http://www.sdf.org.uk/wp-content/uploads/2017/03/ Drugs_Poverty_Literature_Review_2007.pdf

Shezi, S., Everatt, D. \& Jennings, R., 2003, 'Stuck in the margins? An attempt to reverse the failure of rural development in South Africa', Development Update 4(1), 113-139.

Spooner, C. \& Hethringen, K., 2004, Social determinants of drug use. Technical Report Number 228, viewed 26 March 2018, from https://ndarc.med.unsw.edu.au/sites/ default/files/ndarc/resources/TR.228.pdf.Stats SA, 2016, Franschhoek, viewed 13 April 2016, from http://www.statssa.gov.za/?page_id=4286\&id=101

Swart, I., 2013, 'Youth at the margins: Introducing a new research initiative in an ongoing South-North collaboration in the context of international diaconia', Diaconia 4, 2-26. https://doi.org/10.13109/diac.2013.4.1.2

Swart, I., Gouws, A., Pettersson, P., Erasmus, J.C. \& Bosman, F., 2012, Welfare, religion and gender in post-apartheid South Africa: Constructing a South-North dialogue, SUN Media, Stellenbosch.

Terreblanche, S., 2014, Verdeelde land: Hoe die oorgang Suid-Afrika faal, Tafelberg, Cape Town.

Van Laar, S., Cottyn, I., Donaldson, R., Zoomers, A. \& Ferreira, S., 2014, 'Living apart together in Franschhoek, South Africa: The implications of second-home development for equitable and sustainable development', in M. Janoschka \& $\mathrm{H}$. Haas (eds.), Contested spatialities, lifestyle migration and residential tourism, pp. 190-204, Routledge, London.

Vorster, N., 2013, 'Christianity and secularisation in South Africa: Probing the possible link between modernisation and secularisation', Studies in World Christianity 19(2), 141-161. https://doi.org/10.3366/swc.2013.0049 